John Carroll University

Carroll Collected

2020

The Case of the Forgotten Kriminalromane: Rediscovering Otto Soyka's "Metaphysical Detective Stories"

Julia Karolle-Berg

Follow this and additional works at: https://collected.jcu.edu/fac_bib_2020

Part of the German Language and Literature Commons 


\section{The Case of the Forgotten Kriminalromane: Rediscovering Otto Soyka's “Metaphysical Detective Stories"}

Julia Karolle-Berg

Otto Soyka (1881-1955), a Jewish-Austrian author of plays, short stories, and crime and detective novels, died in poverty and obscurity in his hometown of Vienna, yet theatergoers, readers, and critics did not always neglect Soyka's work. An obituary in Neues Österreich praises the author's ability to maintain literary quality across genres, including his masterful style and storytelling skill in writing crime and detective novels (Le. 7). The obituary concludes with the hope that the author's death might occasion the rediscovery of his works, which had mostly become forgotten already in the 1950s (Le. 7).

It is more than sixty years later, and Soyka has yet to gain attention outside a small circle of cognoscenti. Most scholarship has been limited to brief biographies (Garstenauer, "Eine Erinnerung"), short treatments of his works in comparative studies (Holzmann; Linder; Pollet), and entries in literary encyclopedias or histories (Walter; Sprengel). Only one article-length study treats any of Soyka's crime and detective novels in detail (Garstenauer, "Detektivische Befragung"), and his Kriminalromane remain relatively unknown. ${ }^{1}$ In Katharina Hall's 2016 Crime Fiction in German, for instance, Soyka earned no mention in a chapter devoted to Austrian authors of the genre, and his works eluded notice in Hall's search for "readily identifiable texts by Jewish-German, Jewish-Austrian or Jewish-Swiss authors" (24).

Of course, the primary reason that Soyka's works failed to attract the attention of literary scholars for decades was the categorical stigma attached to crime and detective fiction as a popular literary form (Marsch 12). Only since the 1960s has the "Krimi" begun to shake off 
this taint (Kniesche 22), though much significant work to reconstruct the tradition has proven outstanding. In recent years, scholars have sharpened their focus on German-language Kriminalliteratur before 1945, yet in a brief 2018 survey of secondary literature, Charlotte Jaekel still registered the absence of a comprehensive literary history of the genre before 1950 (297).

One of Soyka's fellow authors of crime and detective literature who has enjoyed greater prominence in recent decades is the Swiss writer Friedrich Glauser (1896-1938). Though relatively unknown outside Switzerland until his works were reissued in the 1960s, Glauser is now considered the best-known and most-researched author of German-language Kriminalromane of his time (Cox 322), and his name adorns the coveted prize of the Syndikat, a prominent organization for the advancement of German-language authors of crime and detective fiction. Certainly Glauser's Wachtmeister Studer novels merit the attention they have garnered. Yet Soyka wrote his first detective novel fifteen years earlier than Glauser and was more prolific. Between 1911 and 1936, Soyka published ten volumes explicitly marketed as crime and detective stories; Glauser, just six. ${ }^{2}$ And contemporaries favorably reviewed Soyka as well as Glauser. Renowned cultural and literary critics such as Siegfried Kracauer and Albert Ludwig praised Soyka's Krimis, and the respected author Kasimir Edschmid averred in 1921 that Soyka had written "die einzigen hochwertigen Kriminalromane in Deutschland" (2; see KI. and A.H.S. for praise of Glauser's works). Other reviewers commended the depth of Soyka's characters and conflicts, his provocative social criticism, and his innovative approach to the genre (Wolfradt; Angel). In a genre whose emergent years are still strongly associated with trivial forms and low-quality potboilers of opportunist authors, Soyka's works represent a high- 
water mark (Wolfradt 629; Sprengel 163).

Alongside the problem of finding high-quality German-language Kriminalliteratur from the first decades of the twentieth century, the relative scarcity of methodological or theoretical essays by practitioners of the genre has further hampered efforts to reconstruct its history (Karolle-Berg, "On the Popularity" 307). Here, too, Soyka's works prove valuable given the frequent presence of self-reflexive discourse in them. As I argue below, these texts reveal that, at a time when Arthur Conan Doyle and his epigones dominated the literary landscape and much early twentieth-century crime fiction defended the established world order (Scaggs 20), Soyka's modes and messages were remarkably innovative and provocative.

In this essay, my analysis focuses on the author's first two novels in the genre: Die Söhne der Macht: Ein Zukunfts-Detektivroman (1911) and Das Glück der Edith Hilge: Kriminalroman (1913). These works established Soyka's renown; Die Söhne der Macht earned favorable reviews (Kalkschmidt) and likely secured the serialized publication of Das Glück der Edith Hilge in the Munich-based magazine Zeit im Bild. More particularly, Die Söhne der Macht and Das Glück der Edith Hilge already show Soyka challenging the genre conventions and expectations associated with the "classical" Holmesian detective.

Patricia Merivale and Susan Sweeney's concept of "metaphysical detective stories" provides a productive lens through which to interpret Soyka's experimentations. Though Howard Haycraft originally coined the term in 1941 to characterize G. K. Chesterton's short stories (76; Merivale and Sweeney 4), these later scholars expanded its application to describe

a text that parodies or subverts traditional detective-story conventions-such as narrative closure and the detective's role as surrogate reader-with the intention, or at least the effect, of asking questions about mysteries of being and knowing which 
transcend the mere machinations of the mystery plot. (2)

Among the features that Merivale and Sweeney identify in metaphysical detective stories, two are particularly well represented in Soyka's Kriminalromane: the "defeated sleuth" and the "sheer meaninglessness of clues and evidence" (8). I relate the first concept to Soyka's interruption of the "serialized" detective; the second, I show, finds expression in the unintelligible evidence in the narratives and in the unclear motivations of both detectives and criminals. Supplementing these two features, I identify the attainment of only partial, that is to say biased and imperfect, justice as a recurrent theme in Soyka's novels, one that is congruous with the modes of metaphysical detective stories. Taken together, these devices undermine the sense of certainty, justice, and narrative closure usually attending the conclusion of an investigation.

\section{Defeated Sleuths and Terminated Serialization}

In the introduction to their volume, Merivale and Sweeney locate a central feature of the metaphysical detective story in the "detective's failure to identify individuals, interpret texts, or, even more to the point, solve mysteries" (10). The implications of investigative failure vary for each of the case studies featured in Merivale and Sweeney's collection; in the case of Soyka, defeated sleuths interrupt the well-established practice of serialization, a gesture that denies the social milieu its expected reaffirmation.

In order to flout genre conventions, one must first be aware of them. Many of the conventions of Kriminalromane were already established when Soyka published his first work of Kriminalliteratur in 1911. In the years between the turn of the century and the publication of Die Söhne der Macht, the literary market for Krimis in the German-speaking world was 
dominated by Arthur Conan Doyle's Sherlock Holmes stories, of which eight editions had appeared in German by 1908 (Karolle-Berg, "Between Continuity and Change" 418). Yet about a dozen original, German-language crime-themed novels or short-story collections had also appeared per year during the first decade of the twentieth century (Schädel). Among the better-known authors of shorter crime and detective narratives were Auguste Groner (18501929) and Balduin Groller (1848-1916), while Eufemia von Adlersfeld-Ballestrem (1854-1941) and August WeißI (1871-1922) wrote several popular crime and detective novels.

A common feature of these stories was the deployment of the serialized detective, a strategy that Conan Doyle mastered (Murch 171) and that German-language authors such as these emulated. Although the serialized detective did not become as well established in the German-speaking world as elsewhere (Karolle-Berg, "Between Continuity and Change" 425-27), Groner's police commissioner Joseph Müller and the private investigators Dagobert Trostler and Dr. Franz Xaver Windmüller (created by Groller and Adlersfeld-Ballestrem, respectively) number among the better known of the time.

The recurrence of the same detective in multiple narratives served several functions. Most commonly, it facilitated continuity, predictability, and narrative economy. For example, as Clemens Peck noted with respect to Groller's short stories, the invocation of a particular location and configuration of characters - including a serialized detective - set the stage for Trostler's recounting of a new investigation, a strategy that obviated the need for extended exposition in any given episode (135). By repeatedly invoking a familiar social milieu, serialization also re-presented the successful defense of this milieu against multifaceted threats. Here, the detective acted as a gatekeeper, affirming the milieu's values through his 
investigations (Peck 153). For example, the serialized detectives of Balduin Groller and Eufemia von Adlersfeld-Ballestrem frequently intercepted and neutralized social interlopers, then cleaned up or concealed any resulting social damage (Peck 141; Adlersfeld-Ballestrem 1). Even Sherlock Holmes, an outsider to bourgeois society, ultimately protected "conservative middleclass attitudes towards crime and the maintenance of social order" (Scaggs 25). In Soyka's stories, by contrast, only the parody of a Holmesian detective, Phillip Sonlo, appeared in more than one (Soyka, "Von Philipp Sonlos Erfolgen;" "Sonlo sieht weg").

Soyka did not establish a serialized detective in his novels, but he did lean on the convention of recalling past or future investigations - that is, referred to the serial nature of the detective's work-as a means of establishing the investigator's authority to undertake a new inquiry. In both Die Söhne der Macht and Das Glück der Edith Hilge, private investigators are hired to solve a mystery, and in each, this work is cast as one act in a sequence. Erich Sarto, the lead detective in Die Söhne der Macht and a seasoned veteran, claims a legendary reputation as a formidable opponent, lover of sport, scientist and respected researcher, and man of wealth and charisma (19). This description appears early in the novel and helps establish the adversarial dynamic between him and the equally talented Ernst Herbert Tavera, the mastermind behind the murder that Sarto is hired to investigate. In this way, Soyka sets up serialization through highly recognizable generic structures. Yet at the end of the novel, after neutralizing his enemy, Sarto's immediate impulse is to forget the events that have just transpired: "Sarto suchte sich mit dem Aufgebote seiner ganzen Willenskraft auch von irgendeiner quälenden Erinnerung zu befreien, die ihn weiter verfolgte" (204). Though he never explicitly renounces his career as a detective, it remains unclear whether Sarto will take up 
investigative work ever again.

Sarto never did reappear in Sokya's oeuvre, yet defeated sleuths most certainly do. In Das Glück der Edith Hilge, both a private investigator and a police detective fail to achieve clarity and closure. Whereas the latter, Adalbert Grann, realizes the limitations of his knowledge, the former, Friedrich Gerold, remains oblivious to his professional incompetence. Bookending the main narrative of Das Glück der Edith Hilge are scenes with Gerold. Yet in contrast to the descriptions of Sarto's investigative prowess, less emphasis is placed on Gerold's previous exploits than on his ambitions. Gerold casts himself as an aspiring sequel to Sherlock Holmes: The reader learns, for instance, that Gerold uses stories from English illustrated magazines (9)-implicitly, Conan Doyle's tales-as training manuals (17). Emulating his role model, Gerold claims to be a master of disguise, in top physical shape, and well versed in science (17-18), assertions that recall some of Holmes's most notable attributes as well as Sarto's but sound like absurd braggadocio when narrated in the first person. After clearly bungling his investigation, Gerold's business nevertheless booms with gossip-hungry clients (228), some of whom are likely informants to the eponymous heroine (245), including a young female client who becomes a regular audience for Gerold's tales of ratiocination (230). Indeed, Gerold's anticipation of subsequently narrating his exploits comes to define his investigative work:

Er benahm sich so, wie es sich gut erzählen ließ. Und oft kam es vor, daß er sich seine Rolle in Gedanken vorsagte, während er sie spielte: "Eine unerschütterliche Ruhe beherrschte Friedrich Gerolds Gesicht bei diesem unerwarteten Ereignis." (230)

With the convergence of steady work as a detective and an audience to consume his narratives, Gerold literally becomes a serialized detective à la Sherlock Holmes. In the final sentence of the 
novel, we learn that this affable bungler has even advanced to a coveted position with the police (258).

Soyka's interruption of successful serialized detective work has manifold implications. If solving a case restores social homeostasis in the narrative worlds of Sherlock Holmes, Dagobert Trostler, and Franz Xaver Windmüller, the absence of a successful, serialized detective in Soyka's novels reinforces a sentiment that inquiry does not always result in the containment of social threats, that a return to the old order is impossible. Because of Sarto's ambivalence toward acting as social gatekeeper and his unwillingness to "re-present" his actions, his serialized work appears to cease; the social milieu thus remains unaffirmed and its defenses compromised. In the case of Friedrich Gerold, his work continues, but the social milieu is clearly no safer on his watch.

Looking beyond the plot of this particular story, Soyka may have intended his motif of the interrupted serialized detective as a commentary on the genre of Kriminalliteratur. Perhaps Soyka referred to Die Söhne der Macht as a "Zukunfts-Detektivroman" not only to point to the futuristic society it depicted but also to offer up a "Zukunfts-Detektiv" - a new kind of detective with greater critical potential. As Hall has proposed, for example, in "not having to safeguard the investigative figure," the standalone crime story "allows authors to create uncompromising narratives with radical plots or dénouements" (116). Indeed, through the self-explorations of detectives such as Erich Sarto (a point to which I return below), Soyka's investigators are poised to raise "questions about mysteries of being and knowing" within a changing social context and are able to demonstrate the self-awareness characteristic of metaphysical detective stories (Merivale and Sweeney 2). 
My research has not yet revealed concrete evidence that Soyka's new kind of detective influenced later writers of German-language crime and detective literature, but the author was clearly on to something. Only two years later, a defeated sleuth appeared whose selfterminated serialization left a lasting mark on the Anglo-American crime and detective novel. In 1913, the same year that Das Glück der Edith Hilge appeared, English author E. C. Bentley published Trent's Last Case. Although private detective-cum-reporter Philip Trent had ingeniously solved an earlier case using a method similar to Edgar Allan Poe's C. Auguste Dupin (25; ch. 4), the investigation at the center of Trent's Last Case involves the sleuth "misinterpreting clues, drawing false deductions, and ultimately identifying the wrong culprittwice" (Ashman 182). When others finally reveal to Trent what he is not able to piece together himself, the amateur concedes his "high-blown pride," is humbled by the "impotence of human reason," and vows to put an end to his detective work (163; ch. 16). As scholars such as Nathan Ashman have suggested, Trent's Last Case anticipated the "eventual failure of the 'all seeing, all knowing' ratiocinative detective" (182) and opened up the possibility for a new crime-fiction subgenre in the Anglo-American tradition: the Golden Age clue-puzzle (Ashman 181). This paradigm subsequently dominated crime and detective fiction for decades.

Ironically, Soyka's choice not to rely on a serialized detective may have contributed to the author's subsequent obscurity. As Scaggs has observed, serialized detectives tend to be "a collection of surface details" (36) rather than well-developed personalities, a disposition that ultimately may have had the effect of rendering them more memorable and popular (36). Groner's, Groller's, Adlersfeld-Ballestrem's, and Glauser's deployment of memorable serialized detectives may have thus buoyed their contemporary popularity and facilitated the rediscovery 
of their works after 1945; with his failed detectives, Soyka clearly did not fare as well.

\section{Unclear Motives and Partial Justice}

Up to this point, my analysis has focused on the circumstance that Soyka's sleuths failed. I now take up how and why they are defeated. As I argued above, early twentieth-century crime and detective literature presented the criminal investigator as a gatekeeper of a particular social milieu. One aspect of this gatekeeping is that the detective must weigh the social implications of a perceived crime and, consequently, how justice will be served best with respect to its perpetrators. As Mary Tannert has argued: “Criminal investigation involves not merely ratiocination applied to the physical evidence, but also a society's values with regard to justice and punishment" (45). To take Tannert's notion a step further, I propose that Soyka's works do not just involve scrutinizing "a society's values with regard to justice and punishment" (45) but also the investigator's role in determining what that justice means.

In research on crime and detective fiction, scholars have interpreted detection as a postEnlightenment expression of "scientific and intellectual rationalism [...which] sought to discover the natural laws governing the universe, and human society" (Scaggs 18). Unsurprisingly, human behavior, like material evidence, has been a frequent focus of inquiry in detective stories. The crimes depicted in works of detection presume a motive, plan, and reconstructible causality, and the investigations of them imply that one can reconstruct human behavior in certain circumstances. ${ }^{3}$ Consequently, a significant narrative thread in detective fiction is the attempt to identify a motive for the crime, and through this, the perpetrator. I focus on criminal motives below; for the moment, I turn to a convention that has less frequently attracted the attention of scholars but is of no less importance. By the early 
twentieth century, it had also become standard for the detective's motivations for undertaking an investigation to be explicitly justified.

In Die Söhne der Macht, for instance, the protagonist's impetus for involving himself in a murder investigation comes under scrutiny, and with it, his notion of justice. Sarto's commission to find Fred Fronner and to shed light on Fred's brother Heinz's mysterious death results in the detective's interrogation of his own motivations. In the end, Sarto's resolution marks a breach with his past approach to detection: It is personalized, extrajudicial, and marks the protagonist's withdrawal from-not his reaffirmation of-the social milieu.

As mentioned previously, Sarto, like Sherlock Holmes, is a wealthy, charismatic scientist, and as such, Sarto will accept a case merely for the thrill of the hunt or out of interest in a particular person (20). Sarto's motivation is superficially established early in the narrative through this deployment of the generic trope of "detective as hunter" and sportsman, yet on the several occasions when others ask Sarto why he has taken the case, the detective provides different responses, each seemingly suited to what his interlocutor's own motivations might be. To a man who lost a family member to Tavera, Sarto cites a desire for revenge (29), but to Marfa Andotjewna, the fellow investigator assigned the case, he denies any interest in revenge: "Nie hätte man bloß für eine Rache unsere Aktion ins Leben gerufen, nie wäre ich bereit gewesen, sie zu führen" (50). And to the evil mastermind Tavera, Sarto initially insists that he is not moved by a sense of justice to avenge Heinz's murder:

"Irgend jemandes Bestrafung ist nicht meine Sache. Ich bin mir über die Idee der Gerechtigkeit auch nicht genug im klaren, um es zu wagen, an einem Menschen Rache zu nehmen. Ich glaube, daß diese Idee sich nicht mit dem naiven 'Aug um Aug' decken dürfte" (44). 
When pressed again by Tavera as to why he has deserved Sarto's "attention," Sarto offers his goal, not his motivation: "Ich will Fred Fronner retten" (50). Thus, while a defining aspect of detective inquiry has been the reconstruction of causality between actions and the motivations that spurred them, not even the detective's motives in Die Söhne der Macht are a stable truth, easily reconciled with other information. Indeed, in the moments immediately preceding the adversaries' showdown, Sarto remains ambivalent about his mission: "Wozu das alles, warum war er hier?" (197), he asks himself, and is later even annoyed at having to justify his motives (199). Sarto's profound uncertainty regarding his role as investigator cannot but extend to how he will approach justice.

In the end, Sarto accuses, judges, and has Tavera executed on charges of murder and entrapment (203) and then falsifies the facts of the event for the official record: "An Taveras Körper arbeiteten zwei Ärzte. Sie stellten die eingetretenen Tod fest und konstruierten mit Messer und Skalpell die gewünschte Todesursache" (204). A final scene underscores Sarto's unusually personal involvement in the case: He retreats with Fred and his father to Egypt for Fred's convalescence (205). As Roland Innerhofer has observed, this resolution contradicts Sarto's functionalist, sovereign, and emotionally detached approach to detection (3), and it defies the post-Enlightenment, rational, and impartial pursuit of truth and justice within the rule of law. Sarto's act of revenge does not preserve his moral high ground (Rottensteiner 2), for, as Catherine Belsey has observed: "Revenge is not justice" (qtd. in Scaggs 11). Indeed, because revenge represents a pre-Enlightenment means of conflict resolution, the rejection of revenge as a "possibility of restoring the social order [. . .] is structurally fundamental to much detective fiction" (Scaggs 15). 
Why, then, does Soyka explicitly invoke revenge-an antiquated and partial notion of justice-in what he called a "futuristic" detective novel? On the one hand, this particular resolution is compatible with the nature of the dueling masterminds. Both Sarto and Tavera are endowed with traits that are "no longer" or "not yet" widespread and thus stand outside the boundaries of their present society. Sarto is simultaneously "der modernste der Menschen," yet his image recalls a medieval necromancer (95), and Tavera is described as the descendent of

eines von jenen Adelsgeschlechtern, die dem Italien des Mittelalters seine Tyrannen schenkten. [.. .] Diese Männer der Tat, sie haben das Menschenleben für nichts geachtet und den Mord für ein Vorrecht, das innen zustand (54).

Seen from this perspective, Sarto-incidentally, Italian for "tailor" - fits a punishment to a criminal who places no value on human rights and whose nefarious means slip past the safeguards of the current legal system (81). On the other hand, as I will detail in a later section, a recurrent characteristic of Soyka's detectives is that their knowledge is always "partial," both in the sense of "incomplete" and well as "interested." ${ }^{4}$ When knowledge is partial, justice is also partial. In this case, revenge reflects "partial" justice.

Soyka's depiction of detectives who can attain only partial justice represents another departure from the generic conventions of his time. As J. K. Van Dover opined, the "classical" detective, that is, the character type who dominated the literary landscape when Soyka was writing (see also Lichtenstein 13), exercised his "methodical thinking" to restore order, yet this reassertion of the social order "does not transform, or even affect, the detective" (27). Consistent with Van Dover's assertions, I know of no detectives contemporary with Soyka's Sarto and Grann-Bentley's Philip Trent and parodies notwithstanding - who similarly contemplate the rectitude of their decisions and concede the limits of their knowledge. ${ }^{5}$ After 
Soyka's detectives, Glauser's Wachtmeister Studer may be one of the earliest inspectors in

German-language literature to recognize his errors and ignorance so explicitly. ${ }^{6}$ Yet as Merivale and Sweeney suggest, such epistemological quandaries became more readily accepted in crime and detective literature after 1945 (5).

\section{New Criminals and Unreconstructable Causality}

I have suggested already that detectives work in an established social milieu. According to Van Dover, the world of the "classical" detective "was essentially a well-ordered place" in which "crime was an anomaly." In order to "erase the disruption" of this crime, the detective needed only to "apprehend the perpetrator" (23). Unsurprisingly, Soyka's novels do not depict such "well-ordered" places but rather social landscapes experiencing tectonic shifts through the unprecedented influx of wealth, technology, and new sources of knowledge. The struggle to control these resources has necessarily changed fundamental social dynamics, including what people desire, how they interact with each other, and how they exert their will (see also Ludwig 1218). For Soyka's detectives, this shifting social landscape complicates a fundamental component of discovery: the ability to identify criminal motives and thus reconstruct causality.

Die Söhne der Macht, for instance, captures the new economic and social circumstances created by New York City's wealthiest residents. As the narrator informs us, the laws and fates that have governed all of previous human activity consequently no longer apply to these elites (2). Such circumstances have also enabled the rise of the nefarious Ernst Herbert Tavera, the sort of Machtmensch who would become a recurrent character type in Soyka's novels (Ludwig 1219). Beyond their possession of extreme wealth, these men and women refuse to live according to bourgeois notions of good and evil. The women among them are often femmes 
fatales who embody the noblest as well as the cruelest character traits (for instance, Henriette Berlik in Soyka's Fremdling 123, 130). They possess unprecedented irresistibility, such that their suitors become indifferent to matters of laws and justice (for instance, the eponymous heroine in Das Glück der Edith Hilge 174, 200). For their part, male iterations of the Machtmensch reject the usual notions of humanity (for instance, Andreas Hauffeld in Das Glück der Edith Hilge 185); they desire to gain unprecedented power over people (for instance, Ernst Herbert Tavera in Söhne der Macht 62) and their crimes present a danger to human society that modern criminology and law enforcement cannot contain.

Andreas Hauffeld provides a representative example of the new dangers that the Machtmensch presents. As Grann explains when speaking of Hauffeld:

"Unser Urteil über die Menschen und ihr Tun hat eine feste Voraussetzung, die, daß jeder sich selbst und seine Ziele ernst nimmt. Fehlt diese Voraussetzung, so stehen wir vor einem neuen Problem und vor einem gefährlichen Problem. Wir haben keine Möglichkeit, die Taten eines solchen Menschen zu berechnen, und die Mittel der Justiz, die für andre erprobt sind, versagen ihm gegenüber." (225)

As Grann suggests, Hauffeld does not follow the "laws governing the universe, and human society," precisely the phenomena that the "classical" detective sought to understand in his pursuit of justice (Scaggs 18). When one does not commit crimes for the usual reasons, it is impossible to reconstruct causality; when one cannot reconstruct causality, detection fails. Thus, in societies dominated by Machtmenschen, the power of the modern state to protect its citizens and their possessions in general is compromised. Indeed, such a social order undermines the very notion of the citizen as a self-determining agent (Innerhofer 4). As Soyka suggests, the unchecked Machtmensch has the power to destabilize precisely the social and cultural prerequisites that gave birth to the Kriminalroman to begin with: the modern civil state, 
scientific inquiry, and organized law enforcement.

Meaningless Evidence and Narrative Uncertainty

Besides ascertaining the motives of a criminal, the detective must interpret evidence-material or otherwise-in order to gain clarity and resolution. Yet as in works of metaphysical detective stories such as Die Söhne der Macht and Das Glück der Edith Hilge, the "ambiguity, ubiquity, eerie meaningfulness, or sheer meaningless of clues and evidence" create significant impediments to discovery (Merivale and Sweeney 8). In this section, I consider how uninterpretable evidence necessarily leads to partial knowledge and thus the absence of resolution.

False or unreliable texts pepper Die Söhne der Macht, and in this futuristic detective novel, new technologies and media only exacerbate the meaninglessness of clues and evidence. There are inaccurate media reports $(1-2)$, fake letters $(135,139)$, and a falsified telegram (142); more disturbing is Sarto's mind-bending claim that his nemesis Tavera can even falsify events before they take place (49). When the detective hired alongside Sarto to investigate Heinz Fronner's death, Marfa Andotjewna, confronts Tavera with piles of evidence ostensibly proving his guilt, Tavera parries with his own documents. Andotjewna presents a note in Tavera's handwriting ordering the death of Fronner's father; Tavera produces an identical one in her handwriting. Andotjewna plays an audio recording of Tavera admitting his guilt; Tavera plays a recording in which Sarto and Tavera suspect Adotjewna of the murder (177-81). In this game of charades, an authentic document cannot be distinguished from a forgery (Rottensteiner 2), and consequently, the truth-value of all evidence comes under scrutiny. As Fred Fronner observes to Sarto: "Wahr und falsch ist in unsrer Welt nicht mehr beweisbar. Wir sind wieder auf Treu 
und Glauben angewiesen" (159). For Fred, emotional knowledge is the most decisive: One has to trust one's gut. And so to win the battle against Tavera, Sarto must construct a credible narrative, whether or not it is factually accurate and his modes of inquiry ethical. In the end, as his manipulation of Tavera's death confirms, Sarto's "story" and his putative resolution to the case do not reflect the truth.

Das Glück der Edith Hilge thematizes the contested truth-value of material evidence, but here the focus shifts to the elusiveness of key evidence and the inability of the detectives to interpret what is available. In this novel, Georg Winhard has hired Friedrich Gerold to investigate a murder-Winhard's own. In anticipation of the crime, Winhard furnishes his hotel suite with manifold means of capturing evidence. He greases the doorknob to his bedroom, arranges the furniture to catch clothing fibers on an exposed nail, uses a mechanism to stop the clock when anyone enters his bedroom, layers glue on the carpet to retain footprints, and enables Gerold to eavesdrop on all his conversations with probable suspects (31-36). The stage is thus set for Gerold to undertake what Van Dover described as the primary task of the "classical" detective: to examine the "inert detritus" (that is, material evidence), to "discover what happened" (72).

The accumulated inert detritus is, however, uninterpretable. When Gerold sets about fastidiously interpreting a cigar butt (107), footprints (108), drops of blood (112), and a cufflink (113) at the crime scene, the police investigator assigned the case, Adalbert Grann, proposes plausible and contradictory conclusions for each of Gerold's own (110-18). Besides putting the private detective in his place, Grann takes a shot at the mental gymnastics associated with the Holmesian detective's interpretation of material evidence: ${ }^{7}$ 
"Werden Sie aus der Stellung der Möbel in Ihrer Stube jemals darauf schließen können, wie alt Ihr Stubenmädchen ist, das im Zimmer aufgeräumt hat, welchen Charakter sie hat, welches Kleid sie trug und was sie dabei für Dinge im Kopf hatte? [. . . Hier aber glauben Sie, der Teppich und das Parkett werden zu reden beginnen [...]. Und nur um den Umstand, daß es sich um ein Verbrechen handelt, ist es, der Sie auf die tolle Idee bringt." (109)

As Grann's comments suggest, he does not place much value on material evidence, preferring to engage instead in a psychological-and, as one scholar has argued, literary-analysis of character (Linder 71). In conversing with the judge assigned the case, Grann explains the knowledge he seeks:

"Ich würde die Romane der Personen entwerfen, ihre möglichen Schicksale. Ich würde zu diesen Stimmen, zu diesen Gesichtern die Erlebnisse erfinden, die zu ihnen gehören, und wenn ich meinen Mann auf diesem Weg auch nicht überführen könnte-erkennen würde ich ihn." (151, emphasis in original)

Despite his role as a police inspector, Grann's primary focus is on knowledge ("erkennen würde ich ihn"), not justice. Much like Sarto, Grann tries to create a coherent narrative for each person involved in or affected by the crime. ${ }^{8}$

Jacques Barzun has made the point that detective stories involve "finding out, from circumstances largely physical, the true order and meaning of events that have been part disclosed and part concealed" (249). Yet a common gesture of metaphysical detective stories is that certain mysteries are never fully understood and that the detective's (and therefore the reader's) knowledge remains partial. As Joel Black explains with respect to the purloined letter in Edgar Allan Poe's story of the same name:

Very little is finally revealed about the object of the detective's quest, or about why it should be so valuable; to do so would diminish the reader's interest in the quest, as well as the reader's sense of the object's prestige [...]. The prize object appears invaluable precisely because it is inaccessible and unintelligible. (80) 
Consistent with metaphysical detective stories such as "The Purloined Letter," Soyka perpetuates the mystery surrounding Edith Hilge by granting the reader only partial insight into her character. Hilge never appears in person. Yet in order to understand Winhard's murder, one has to understand Winhard's relationship to the eponymous heroine and what is frequently referred to in the text as "Das Glück der Edith Hilge" (82, 174, 176, 181, 239). When one of Winhard's acquaintances discourses on this topic, however, Gerold is asleep at his post (87). The detective does not recognize Edith Hilge's happiness as a motive for the crime, and because Gerold fails to capture the conversation, the reader is denied access to its particulars. After the murder has been committed and police inspector Adalbert Grann takes over the investigation from Gerold, he seeks out Hilge. Yet the woman disappears before Grann can question her (195-96), and Hilge's portrait, which the police inspector views briefly, is violently removed from its frame and later disappears $(190,255)$. When Grann sneaks a look at Gerold's girlfriend, a woman whom Grann suspects is Hilge in disguise, the inspector does not see Hilge in her (231). Given Grann's other failures in the investigation, the reader is likely to wonder if the woman is, indeed, Hilge but Grann merely fails to recognize her. In such a reading, Hilge remains "inaccessible and unintelligible" (Black 80 ) to Grann even when she is presented to him; the investigator's quest for Erkenntnis remains unfulfilled.

In the end, Winhard's murder cannot be solved conclusively through the examination of physical evidence or the psychological exploration of the suspects' characters and motives. Grann concedes that he, like Gerold, has bungled the investigation. When the presiding judge nevertheless presses Grann to name a perpetrator, the police inspector indicates that precisely because he has gained greater insights into, and thus respect for, humanity, he cannot render a 
judgment over any of the four accused (254). Grann's knowledge therefore does not translate into justice, and the novel offers no closure: Both the mystery surrounding Edith Hilge's appeal and Georg Winhard's murder remain concealed.

The absence of closure is a characteristic feature of metaphysical detective stories (Merivale and Sweeney 2), and it suggests another way in which Soyka's novel challenged contemporary generic conventions and even drew fire. In 1913, concurrent with a serialized printing of Das Glück der Edith Hilge, the Munich-based magazine Zeit im Bild invited its audience to solve the murder of Georg Winhard, offering a 100,000-Mark prize and initiating a striking reversal of the usual triumph of sleuth over reader. The challenge appeared to have been a successful marketing tool, helping to spur eleven reprintings of the book in the last three months of 1913 alone (Garstenauer, "Detektivtische Befragung" 576). Yet an epilogue to later editions of the novel shows Soyka deflecting criticism for having failed to identify Winhard's murderer more explicitly (259). It would appear that readers were frustrated (in both senses of the word) in their anticipated role as a "classical" detective, that is, one whose "principal drive is to eliminate the uncertainty, and [whose] world always enables him to do so" (Van Dover 63). Instead, as Joachim Linder has observed, by bestowing his readers with the freedom and burden to solve the mystery themselves, Soyka only reinforces that certainty cannot be achieved in this Krimi (71).

\section{Conclusion}

In this essay, I have suggested that Otto Soyka's Kriminalromane present new and insightful resources for research into German-language crime and detective literature before 1945. My primary focus here has been to read Soyka's work as metaphysical detective stories and thus 
works that intentionally challenge conventions and expectations of the genre.

One implication of reading Soyka's novels in this manner is that it complicates assertions by many critics contemporary with Soyka that the genre was, by definition, trivial. A position asserted in a 1910 debate on the merits of the Kriminalroman elucidates this point. Here, literary scholar Johannes Siebert recognizes the centrality of suspense to the plot of Krimi, yet sees it as a feature that simultaneously undermines the genre's literary value: "Mit dem Lösen der Spannung fällt der Wert eines Kriminalromans zusammen wie ein Gerüst, dessen Grundpfeiler man hinwegreißt." Quoting a verse by the nineteenth-century German poet Friedrich Rückert, Siebert concludes that the very essence of this genre - the tension-filled drive toward resolution-renders it a literary form without merit: "Doch was nicht zweimal lesenswert gewesen, das ist nicht einmal lesenswert" (127, emphasis in original). Though attitudes toward the Kriminalroman have become more accommodating even in the Germanspeaking world since Siebert offered his perspective, the challenge of writing ambitious crime and detective literature persists. In his contribution to Merivale and Sweeney's volume, John Irwin considers: "How does one write analytic detective fiction as high art when the genre's basic structure, its central narrative mechanism, seems to discourage the unlimited rereading associated with serious writing?" (27). It has been my contention that Otto Soyka's novels, particularly Das Glück der Edith Hilge, offer a response. One wonders how Siebert would have reacted to a Krimi such as Das Glück der Edith Hilge, which does not expose mysteries, resolve suspense, or assert certainty. If such novels can be read more than once, do they rise above triviality, or do they simply fail at being Kriminalromane? Obviously, my argument here has been that, like other metaphysical detective stories, they engage with the genre even as they 
instantiate it.

A second, significant implication of rediscovering Soyka's Krimis is that this corpus stands to enrich our understanding of the evolution of German-language crime and detective stories. Soyka's works engage with several themes that recur in later authors' works; integrating his crime and detective stories into this legacy is tantamount to discovering a longforgotten ancestral line. As Gabriela Holzmann has observed, for instance, Soyka's criminals anticipated Norbert Jacques's better-known scoundrel, Dr. Mabuse (136-37n). Similarly, Fritz Lang's and Werner Bergengruen's explorations of ways of knowing and the limits of justice in $M$ (1931) and Der Großtyrann und das Gericht (1934), respectively, recall the dilemmas of Soyka's detectives. Looking to international trends, the hard-boiled school of detection echoes Soyka's lack of faith in the order of the world. Finally, in presenting a highly individualized and ultimately extrajudicial resolution to Die Söhne der Macht, Soyka's novel anticipates themes that Friedrich Dürrenmatt developed in his quintessentially metaphysical detective story, Der Richter und sein Henker (1952).

This essay opened with a comparison between Soyka and Friedrich Glauser, a Swiss contemporary of Soyka's who has garnered significantly more scholarly attention than his Viennese counterpart. One pronounced difference between Glauser and Soyka remains that, with the exception of Soyka's Die Traumpeitsche $(1921,1995)$, none of this author's works have been reissued in recent years, whereas Glauser's collected works have reappeared in painstakingly researched editions. Yet if, in reconstructing the genre's history, scholars focus only on Kriminalromane that are readily available, we run the risk of resembling the proverbial man who looks for his house key under the street lamp not because he dropped it there, but 
because it would be easiest to find under the light. In reconstructing the history of Germanlanguage Kriminalromane, I suggest that instead of looking only at highly visible sources, we also consider literature that has long remained in obscurity.

Julia Karolle-Berg is Professor of German at John Carroll University near Cleveland, Ohio. She joined the JCU faculty in 2002 and teaches all levels of German language and culture. Her research focuses on twentieth-century popular literary forms, particularly early Germanlanguage detective novels. Two essays that appeared in 2018 were "Between Continuity and Change: Early Twentieth-Century German-Language Crime and Detective Novels and the 'Familienkrimi,'" in German Life and Letters and "On the Popularity of the Kriminalroman: The Reception, Production, and Consumption of German Crime and Detective Novels (1919-1933)," in German Quarterly. Karolle-Berg is currently writing a literary history of popular Germanlanguage crime and detective fiction from the turn of the last century to the mid-1930s.

Notes

1. The terms Kriminalroman and Detektivroman were used interchangeably during the 1910s. I therefore refer to German-language crime and detective novels with the umbrella term Kriminalromane or Krimis. Because crime and detective fiction may include shorter forms, I refer at times to Kriminalliteratur.

2. Some ambiguity exists regarding precisely how many Krimis Soyka wrote. Mirko Schädel lists twenty-four works by Soyka in his bibliography of crime literature (2:226-38), but not all of them were marketed explicitly as Kriminalromane or characterized as such in contemporary book reviews. By contrast, the Lexikon der Kriminalliiteratur, which appeared in the 1990s, treats nine of Soyka's novels.

3. As Scaggs observed, the "unplanned' street crime and [acts of] gangsterism" that were typical and on the rise in second half of the nineteenth century were never the focus of investigation for the detectives of this era (42).

4. My gratitude to my colleague, John McBratney, professor of English at John Carroll University, for sharing his notion of "partial" knowledge with me.

5. See, for instance, Artur Landsberger's Der Fall Hirn (1917), in which a man wins an intellectual duel with the Meisterdetektiv Pino.

6. In his first case, Studer feels empathy for a known murderer, and in a subsequent one he 
concedes his failure to understand the case (Karolle-Berg, "Fahnderwachtmeister Jakob Studer"175-76).

7. See, for instance, Sherlock Holmes's extrapolation of the character and habits of Watson's deceased brother based on the material evidence of his watch in Sign of Four (Conan Doyle 92 ; ch. 1).

\section{Works Cited}

A.H.S. "Ein bernischer Kriminalroman." Der Bund [Berne], evening edition, 10 December 1936, p. 10.

Adlersfeld-Ballestrem, Eufemia von. Weiße Tauben. 1906. Seyfert, 1912.

Angel, Walter. Review of Eva Morsini, die Frau, die war . . by Otto Soyka. Neue Freie Presse, 26 August 1923, no. 21179, p. 24.

Ashman, Nathan. "Philip Trent." 100 Greatest Literary Detectives, edited by Eric Sandberg, Rowman \& Littlefield, 2018, pp. 181-83.

Barzun, Jacques. "Detection and the Literary Art." The Mystery Writers' Art, edited by Francis Nevins, Bowling Green State U Popular Press, 1970, pp. 248-62.

Bentley, E. C. Trent's Last Case. 1913. Dover, 1997.

Bergengruen, Werner. Der Großtyrann und das Gericht. Hanseatische Verlags-Anstalt, 1934.

Black, Joel. “(De)feats of Detection: The Spurious Key Text from Poe to Eco.” Detecting Texts: The Metaphysical Detective Story from Poe to Postmodernism, edited by Patricia Merivale and Susan Elizabeth Sweeney, U of Pennsylvania P, 1999, pp. 75-98.

Cox, Christoph. "Kriminalliteratur zur Zeit des Nationalsozialismus." Handbuch Kriminalliteratur: Theorien-Geschichte-Medien, edited by Suanne Düwell et al., Metzler, 2018, pp. 32025.

Doyle, Arthur Conan. "The Sign of Four." The Complete Sherlock Holmes, vol. 1. Doubleday, [1930], pp. 88-158.

Dürrenmatt, Friedrich. Der Richter und sein Henker. 1952. Rowohlt, 1965.

Edschmid, Kasimir. “Deutsche Erzählungsliteratur.” Frankfurter Zeitung, no. 546, 26 July 1921, pp. 1-2.

Garstenauer, Werner. “Detektivische Befragung einer Generation: Otto Soykas Literarisierung 
der Massenpsychologie." Estudios Filológicos Alemanes, vol. 15, 2008, pp. 573-83.

- - . "Eine Erinnerung an den Wiener Romancier Otto Soyka: Expressionist und 'Psychosoph.'” Wiener Zeitung, 23 February 2001. www.archive.li/H4bcX. Retrieved 16 January 2017.

Hall, Katharina. "Crime Fiction in German: Concepts, Developments and Trends." Crime Fiction in German: Der Krimi, edited by Katharina Hall, U of Wales P, 2016, pp. 1-32.

- - . "Historical Crime Fiction in German: The Turbulent Twentieth Century." Crime Fiction in German: Der Krimi, edited by Katharina Hall, U of Wales P, 2016, pp. 115-31.

Haycraft, Howard, Murder for Pleasure: The Life and Times of the Detective Story. AppletonCentury, 1941.

Holzmann, Gabriela. Schaulust und Verbrechen: Eine Geschichte des Krimis als Mediengeschichte (1850-1950). Metzler, 2001.

Innerhofer, Roland. "Die Söhne der Macht. Ein Zukunfts-Detektivroman." Werkführer durch die utopisch-phantastische Literatur, edited by Franz Rottensteiner and Michael Koseler, vol. 8, Corian, 1989-, pp. 1-4.

Irwin, John. "Mysteries We Reread, Mysteries of Rereading: Poe, Borges, and the Analytic Detective Story." Detecting Texts: The Metaphysical Detective Story from Poe to Postmodernism, edited by Patricia Merivale and Susan Elizabeth Sweeney, $U$ of Pennsylvania P, 1999, pp. 27-54.

Jacques, Norbert. Dr. Mabuse, der Spieler. Ullstein, 1920.

Jaekel, Charlotte. "Kriminalliteratur von 1900 bis zum Ende des Ersten Weltkriegs." Handbuch Kriminalliteratur: Theorien-Geschichte-Medien, edited by Suanne Düwell et al., Metzler, 2018, pp. 297-302.

Kalkschmidt, Eugen. "Neue deutsche Erzählungsliteratur." Frankfurter Zeitung, vol. 57, 26 February 1913, p. 1.

Karolle-Berg, Julia. "Between Continuity and Change: Early Twentieth-Century GermanLanguage Crime and Detective Novels and the 'Familienkrimi.'” German Life and Letters, vol. 71, no. 4, October 2018, pp. 415-33.

- - - "Fahnderwachtmeister Jakob Studer." 100 Greatest Literary Detectives, edited by Eric 
Sandberg, Rowman \& Littlefield, 2018, pp. 174-76.

- - - "On the Popularity of the Kriminalroman: The Reception, Production, and Consumption of German Crime and Detective Novels (1919-1933)." German Quarterly, vol. 91, no. 3, 2018, pp. 305-21.

KI. "Friedrich Glauser: Wachtmeister Studer." National-Zeitung [Basle], 22 December 1936, no. 596, n.p.

Kniesche, Thomas. Einführung in den Kriminalroman. Wissenschaftliche Buchgesellschaft, 2015.

Le. "Otto Soyka gestorben." Neues Österreich, vol. 11, no. 282, 4 December 1955, p. 7.

Landsberger, Artur. Der Fall Hirn: Eine Detektivgeschichte. Georg Müller, 1918.

Lang, Fritz, dir. M: Eine Stadt sucht einen Mörder. Nero Film, 1931.

Lichtenstein, Alfred. Der Kriminalroman: Eine literarische und forensische Studie mit Anhang: Sherlock Holmes zum "Fall Hau." Reinhardt, 1908.

Linder, Joachim. "Die Polizei als Reflexionsinstanz. Ermittlung in Kriminalromanen von Otto Soyka, Heimito von Doderer und Ernst Jünger." Doderer, Das Kriminelle und der literarische Kriminalroman, edited by Gerald Sommer and Robert Walter, Königshausen \& Neumann, 2011, pp. 69-90.

Ludwig, Albert. “Otto Soyka." Das literarische Echo, vol. 21, no. 20, 15 July 1919, cols. 1217-23. Marsch, Edgar. Die Kriminalerzählung: Theorie-Geschichte-Analyse. 2nd ed., Winkler, 1983. Merivale, Patricia, and Susan Sweeney. "The Game's Afoot: On the Trail of the Metaphysical Detective Story." Detecting Texts: The Metaphysical Detective Story from Poe to Postmodernism, edited by Patricia Merivale and Susan Elizabeth Sweeney, $\mathrm{U}$ of Pennsylvania P, 1999, pp. 1-26.

Murch, A. E. The Development of the Detective Novel. Philosophical Library, 1958.

Peck, Clemens. "Im Panikraum des Liberalismus: Balduin Grollers Wiener Sherlock Holmes." Kriminalliteratur und Wissensgeschichte: Genres-Medien-Techniken, edited by Clemens Peck and Florian Sedlmeier, transcript, 2015, pp. 127-58.

Pollet, Jean-Jacques. "Fictions policières archaïques des lettres allemandes." Germanica, vol. 3, 1988, pp. 31-50.

Rottensteiner, Franz. "Die Söhne der Macht. Ein Zukunfts-Detektivroman." Lexikon der 
Kriminalliteratur: Autoren, Werke, Themen, Aspekte, edited by Klaus-Peter Walter, part 2, vol. 6, Corian, 1993-, pp. 1-3.

Scaggs, John. Crime Fiction. Routledge, 2005.

Schädel, Mirko. Illustrierte Bibliographie der Kriminalliteratur im deutschen Sprachraum von 1796 bis 1945. 2 vols., Achilla, 2006.

Siebert, Joh[annes]. "Zur Frage der Kriminalliteratur." Die Hochwacht: Monatsschrift zur Pflege deutscher Art daheim und draußen, vol. 1, no. 4, 1910/11, pp. 126-27.

Soyka, Otto. Eva Morsini, die Frau, die war. . . . Drei Masken, 1923.

- - Der Fremdling. Albert Langen, 1910.

- - Das Glück der Edith Hilge: Kriminalroman. 1913. Schuster \& Loeffler, 1919.

-- - Die Söhne der Macht: Ein Zukunfts-Detektivroman. Albert Langen, 1911.

- - . "Sonlo sieht weg." Das Kleine Blatt [Vienna], vol. 6, no. 176, 26 June 1932, pp. 3-4.

- - Die Traumpeitsche. 1921. Suhrkamp, 1995.

- - - "Von Philipp Sonlos Erfolgen." Der Griff aus dem Dunkel: Detektivgeschichten zeitgenössischer Erzähler, edited by Karl Lerbs, Singer, 1924, pp. 191-206.

Sprengel, Peter. Geschichte der deutschsprachigen Literatur 1900-1918: Von der Jahrhundertwende bis zum Ende des Ersten Weltkriegs. Beck, 2004.

Tannert, Mary. "The Emergence of Crime Fiction in German: An Early Maturity." Crime Fiction in German: Der Krimi, edited by Katharina Hall, U of Wales P, 2016, pp. 33-50.

Van Dover, J. K. We Must Have Certainty: Four Essays on the Detective Story, Susquehanna UP, 2005.

Walter, Klaus-Peter, ed. Lexikon der Kriminalliteratur: Autoren, Werke, Themen, Aspekte. Part 2, Corian, 1993-.

Wolfradt, Willi. Review of Der entfesselte Mensch, by Otto Soyka. Die Weltbühne, no. 48, 25 November 1920, pp. 629-30. 